Smulders, P., Batenburg, R. Onderzoek naar trends in arbeid: niet populair in universitaire kringen. Tijdschrift voor Arbeidsvraagstukken: 2010, 26(4), 355-357

\begin{tabular}{|l|l|}
\hline Postprint Version & 1.0 \\
\hline Journal website & $\underline{\text { http://www.boomlemmatijdschriften.nl/tijdschrift/TvA/2010/4/TvA_2010_026_ }}$ \\
\hline Pubmed link & $\underline{004 \_001}$ \\
\hline DOI & \\
\hline
\end{tabular}

This is a NIVEL certified Post Print, more info at http://www.nivel.eu

\title{
Onderzoek naar trends in arbeid: niet populair in universitaire kringen
}

\author{
PETER SMULDERS EN RONALD BATENBURG
}

Kranten en tijdschriften zijn gek op informatie over trends of ontwikkelingen in de tijd. Je kunt geen krant openslaan of je komt wel een bericht tegen met dit soort onderwerpen. Enkele recente koppen:

'Telewerken wint aan populariteit'

'MKB verliest dit en volgend jaar ruim 200.000 banen'

'Vrouw steeds vaker eigen baas'

'Meer geld voor banen jongeren'

'Geweld openbaar vervoer stijgt in provincie'.

Niet alleen in kranten, maar ook in inleidingen van sociaalwetenschappelijke artikelen worden termen als 'steeds meer' en 'meer dan ooit' graag gebruikt. Soms blijken het ongefundeerde termen te zijn en alleen goed om de aandacht van de lezer te trekken of vast te houden. Want ze worden pas terecht gebruikt als ze onderbouwd zijn met valide trendgegevens. En die zijn schaars.

Op het gebied van arbeid kunnen we in Nederland onder meer beschikken over omvangrijke en representatieve databestanden van het CBS, TNO, UWV (voor arbeidsongeschiktheid) en tot voor kort OSA. Het Sociaal en Cultureel Planbureau verzamelt soms eigen data en belicht frequent arbeidsmarkt- en socialezekerheidsontwikkelingen in de tijd.

In Europees verband zijn data beschikbaar van Eurostat, de OESO en de European Foundation for the Improvement of Living and Working Conditions (EFILWC) in Dublin. De Europese Unie heeft in het kader van de European Employment Stategy een set indicatoren - de zogenaamde Laeken-indicatoren vastgesteld om de kwaliteit van het werk te monitoren. Met behulp van EFILWC-data 1990-2010 zijn trends in de tijd, verschillen tussen EU-landen en clusters daarin in kaart gebracht (bijv. Smulders, 2004; Davoine et al., 2008). In de Verenigde Staten verzamelt het Bureau of Labor Statistics (BLS) van het Department of Labor in Washington trendgegevens via een aantal doorlopende registraties en surveys. BLS publiceert - bijvoorbeeld in het Monthly Labor Review - over productiviteit, werkgelegenheid en werkloosheid, lonen, uitkeringen, pensioenen, collectieve arbeidsovereenkomsten, arbeidsconflicten, werktijden, overwerk, veiligheid en ongevallen op de werkplek, enzovoort. Trouwens, ook de Ministeries van Arbeid van andere Westerse landen (Australië, Canada, Duitsland, Frankrijk, de Scandinavische landen) houden er eigen onderzoeksbureaus op na of hebben een vaste relatie met hun eigen nationale statistiekbureau. In Nederland voert het CBS onderzoek uit in overleg met bijvoorbeeld het Ministerie van SZW. Dollard et al. (2007) publiceerden een mooi overzicht van wat er in 35 monitoringsystemen in 20 Westerse landen beschikbaar is op het gebied van 'psychosocial risk factors in the workplace'.

Onder universitaire wetenschappers die zich met arbeid en organisatie bezighouden is gebruikmaking van grote nationale of internationale databestanden en monitoring-, surveillance- of trendonderzoek niet erg populair. Searches in The Web of Knowledge bevestigen deze indruk. Nederlandse sociologen, psychologen en economen verbonden aan universiteiten, lijken data van het CBS of Eurostat vaak alleen te gebruiken ter illustratie of ter ondersteuning van hun probleemstelling of hun resultaten. Daadwerkelijke analyse van CBS- en Europese data laten ze meestal over aan statistische bureaus zelf of aan instanties als bijvoorbeeld SCP, ROA en TNO, terwijl genoemde instanties hun data toch ook beschikbaar stellen voor gekwalificeerde buitenstaanders.

Dat alles is alleen al jammer voor de vaak zeer relevante data die door een bureau als het CBS worden 
verzameld. Wat arbeid en sociale zekerheid betreft, zie men de CBS-website (CBS, 2010a). Ook is het totale aandachtsgebied van CBS-onderzoek er te vinden (CBS, 2010b).

Het CBS stelt ook faciliteiten beschikbaar voor onderzoekers. Zij kunnen on site werken of via 'remote access' toegang krijgen tot microdatabestanden om onderzoek te doen. Het Centrum voor Beleidsstatistiek is hier bij het CBS verantwoordelijk voor.

Wat kunnen de oorzaken zijn van die beperkte universitaire interesse voor analyse van grote doorlopende bestanden? Praktische redenen als onwetendheid over welke data er beschikbaar zijn en hoe eraan te komen, zullen simpelweg meespelen. Maar ook de voorkeur voor eigen concepten en eigen operationalisaties, die mogelijk net niet aanwezig zijn in doorlopende nationale of internationale surveys (externe onderzoekers zouden trouwens best een mening mogen hebben en die onder woorden brengen over wat statistische bureaus wel en niet verzamelen). Verder speelt bij universitaire onderzoekers de voorkeur voor causale designs een rol, liefst met longitudinale data, waar internationale tijdschriften tegenwoordig bijna een sine-qua-non van maken. Ten behoeve van het hoge doel van longitudinaal onderzoek met eigen concepten en operationalisaties behelpt men zich dan met kleine, niet-representatieve steekproeven, soms samengesteld uit universitaire studenten. Onderzoek met en uitspraken over representatieve data spelen in universitaire kringen vaak een minder grote rol dan het blootleggen van causale verbanden met beperkte reikwijdte.

Een argument voor universitaire onderzoekers om juist wel aan trendanalyses aandacht te besteden is dat trends de onderzoeksprogramma's kunnen prioriteren en ook er nadere causale analyses mee beargumenteerd kunnen worden. Als op basis van trendanalyses geconstateerd wordt dat ouderen, vrouwen en zelfstandigen het laatste decennium in grotere aantallen de arbeidsmarkt hebben betreden, ligt de vraag naar empirisch-onderbouwde oorzaak-gevolgrelaties voor de hand. Wat zijn de motoren daarachter geweest? Of als in trendanalyses geconstateerd wordt dat computerisering op het werk overweldigend gestegen is, doet zich de onderzoeksvraag voor naar de effecten op gezondheid en welzijn. Zo is ook de internationalisering en globalisering van het bedrijfsleven op basis van grote databestanden te onderbouwen. Maar het antwoord op de afgeleide vraag naar wat de effecten ervan zijn op de in de toekomst gevraagde opleidingen en de organisatiewijze staat relatief in de kinderschoenen.

Wij houden, kortom, zowel een pleidooi voor intensiever gebruik van grote nationale en internationale databestanden als het blootleggen van trends in de tijd. Deze aflevering van het Tijdschrift voor Arbeidsvraagstukken omvat zulke trendanalyses, van de hand van een aantal in ons vakgebied gerenommeerde auteurs. Daarbij zijn we erin geslaagd artikelen bijeen te brengen die centrale thema's van ons tijdschrift beslaan, te weten het thema sociale zekerheid (zie de bijdrage van Cok Vrooman), arbeidsmarkt en arbeidsmarktbeleid (Jaap de Koning), vrouwen op de arbeidsmarkt (Anneke van DoorneHuiskes en Joop Schippers), arbeidsverhoudingen (Kees Vos) en kwaliteit van de arbeid (Irene Houtman en Seth van den Bossche) en arbeidsorganisatie (Jos Benders en collega's). Deze artikelen worden gelardeerd met de columns van auteurs die eveneens hun sporen in het vakgebied van de arbeidsvraagstukken verdiend hebben: Paul Schnabel, Alexander Rinnooy Kan en Jules Theeuwes. De frequente bijdrage van het CBS aan de recente jaargangen van TvA wordt ook nu in lijn met het centrale thema ingevuld door Harry Bierings, Boukje Janssen en Bob Lodder.

\section{LITERATUUR}

CBS (2010a). http://www.cbs.nl/nl-NL/menu/themas/arbeid-sociale-zekerheid/beschrijving/default.htm CBS (2010b). http://www.cbs.nl/nl-NL/menu/methoden/dataverzameling/default.htm

Davoine, L., Erhel, Chr., Guergoat-Larivière, M. (2008). Monitoring quality in work: European employment strategy indicators and beyond. International Labour Review, 147, 163-198.

Dollard, M., Skinner, N., Tuckey, M.R. \& Bailey, T. (2007). National surveillance of psychosocial risk factors in the workplace: an international overview. Work \& Stress, 21, 1-29.

Smulders, P. (2004). Work in 27 European countries: testing the North-South hypothesis. Tijdschrift voor Arbeidsvraagstukken, 20, 231-287. 